\title{
Gender Discourses in Positioning Indonesian Female Migrant Workers
}

\author{
Wening Udasmoro', ${ }^{1}$ Setiadi ${ }^{2}$ \\ ${ }^{1}$ Department of Language and Literature, Universitas Gadjah Mada, Indonesia (email: udasmoro@ugm.ac.id) \\ ${ }^{2}$ Department of Anthropology, Universitas Gadjah Mada, Indonesia (email: setiadi_antro@ugm.ac.id)
}

\begin{abstract}
Indonesian female migrant workers are a group that has over time experienced physical, psychological, and verbal violence in their jobs in foreign countries. The story presented of the struggles of this subordinated group of women remains one-sided and incomplete. The untold part of the story are the experiences they have encountered domestically from within their own country, Indonesia. This article argues that the subordinated position of Indonesian female migrant workers is initially created and strongly reinforced through the discrimination they face within specific social settings in the Indonesian context. One such social setting is at Indonesian international airports. Indonesian international airports are where the female migrant workers are positioned as "others"; rules put in place and their enforcement by airport officials and other passengers show the exclusion of female migrant workers from Indonesian society. Such positioning is an act of discrimination, exploitation, and exercise of power. This study examines what discourses are used in positioning these Indonesian female migrant workers in Soekarno Hatta International Airport, Jakarta. The authors argue, using research data and gender theories, that the positioning of Indonesian female migrant workers is a discursive act. It is committed by various individuals, particularly those (in the power system) that have the position of "we" and "us", to preserve the social classes, which have become normalized throughout Indonesian history. The research found that the discrimination against female migrant workers is strongly connected to their social class. Although they have financial capital, their position is considered lower than other people in the airport, which creates multiple forms of discrimination, from material to symbolic discrimination and stereotypes.
\end{abstract}

\section{Keywords:}

agency, discrimination, symbolic, verbal, violence

\section{Introduction}

The Ministry of Labor through Decree No.260 of 2015 initiated a moratorium on sending Indonesian migrant workers abroad. It was especially focused on the temporary prohibition of the placement of Indonesian migrant workers with individual employers in the Middle East (Platt, 2018). This regulation was a follow-up to the Decree of the Minister of Labor No. 22 of 2014 regarding the placement and protection of Indonesian workers abroad. A moratorium was needed to change Indonesian foreign policy by the shift toward a more democratic policy (Elias, 2013), to improve migrant worker protection, rights, and welfare (Platt, 2018), reduce informal migrant workers (Mafruhah et al., 2016), and increase the state control over the labor migration process (Killias, 2010). Although this action was criticized by NGOs such as Migrant Care, which explained that the moratorium would be ineffective and increase illegal human trafficking, the government cited the need to prevent physical violence against migrant workers. The government argued that the moratorium would protect the migrant workers 
from the dangerous environment (Kusuma et al., 2015) and harsh treatment (Ford, 2006) particularly in the Middle East. Drawing on data from the Ministry of Education, Ministry of Foreign Affairs, Indonesian embassies, and victims' families, Migrant Care concludes that 874 Indonesian migrant workers experienced violence or abuse in 2010. In 2011, cases of rape and sexual assault of migrant workers increased to 1,234 from 1000 cases in 2010 (Solidaritas Perempuan, 2014). Between 2007 and 2012, 151 migrant workers were shot by Malaysian police without any clear legal basis. Cases of physical violence against Indonesian migrant workers continued to increase from 2015 to 2016. One province that sent its migrant workers abroad, West Nusa Tenggara, reported more than 500 cases of violence in 2015 and more than 900 cases of violence in 2016 (Radar Lombok, 2016). These statistical facts were some of the considerations for implementing the moratorium on sending Indonesian migrant workers to the Middle East.

While the protection (mainly physical) offered by the government is essential, several other significant measures have yet to be taken. Foremost among these is protecting female migrant workers from symbolic and verbal violence at the hands of government employees and individual citizens. Most articles about Indonesian migrant workers focus on how the regulations have protected their rights (Kristina, 2020) and how families have been affected by workers' travels abroad, especially their impact on financial and social life (Spitser, 2016; Anomsari, 2020). Some articles are focused on looking at the role of the social capital in that process (Pratikno et al., 2020) and how the female migrants experience more exploitation when they work in other countries (Loveband, 2007). Other research focuses more on life courses of migration (Liao \& Gan, 2020). Other issues also capture the researchers' attention, such as the detrimental effects of migrant workers' departures on their family live, including cases of adultery, gender and social structure (Anggaunitairanantika \& Hamidi, 2020) and bad marriage situations. Other studies focus on quantitative issues from whence and to where migrant workers travel (Sururama \& Nanuru, 2019), such as the pattern of mobility from one country to other countries (Setiadi, 2001); (Keban, 2000). In contrast, NGO reports tend to focus on human rights, particularly questions of advocacy such as access to legal support and government action to protect migrant workers. Moreover, some research studies have also examined how the migrant workers are exploited, particularly financially, by the host country (Chan, 2014). The most recent issues to draw considerable attention have included the trafficking of women and children and rescuing the migrant returning from other countries. For almost two decades, academic discourse has focused predominantly on the relationship between migrant workers and the State, such as with State institutions and the situation migrants face abroad as victims of physical violence at the hands of other individuals.

Unlike these previous studies, this study attempts to explain the experiences of symbolic violence faced by migrant workers in their interactions with individuals within an important space, the international airport in Indonesia. This study involved qualitative research and examined female migrant workers from a gender perspective. The research questions include: how is the international airport space used by airport officials and passengers to position the female migrant workers in their interactions? How do airports function to marginalize these Indonesian female migrant workers? In this delimited space, what discourses are often used to differentiate the "self" and "others" in this positioning?

This paper is intended to examine the positioning of the female migrant workers by various subjects. It is vital to research this positioning because it is in these delimited 
spaces that relationships of power and forms of dominance are often manifested to meet symbolic goals. The relationships of power are for instance exercising power over those considered to be of a lower social class or for material goals, such as to obtain financial benefit from the female migrant workers. Examining the power relationship is essential because it has an effect on people's everyday practices (Butler, 1988).

Research for this paper was conducted between 2013 and 2017, focusing on the narratives presented by migrant workers and people having experience and knowledge about the migrant workers' issues. The observations were conducted in SoekarnoHatta International airport in Jakarta by focussing on how the female migrant workers were treated by the immigration officers and other passengers. There were five observations conducted. Interviews were conducted with fifteen people and, a sample is presented in this report. From these informants, three were the female migrant workers interviewed in the airport. The remaining twelve informants interviewed were six people from Central Java, and six people from Yogyakarta. In terms of gender, of the twelve informants, six of them were male. The informants came from different social backgrounds. They had different professional backgrounds and occupations, such as lecturers, government employees, students, teachers, and housewives. Central Java and Yogyakarta were chosen because these two places had different patterns of female migration. Yogyakarta was considered having low numbers of female migrant workers abroad, around 820 people in 2016, however Central Java was considered having quite a high number of female migrant workers, around 57.000 individuals in 2015, which decreased from 92.590 in 2014 (Amr., 2016). Research also involved observing the narratives presented in the airport, including notices on boards and other relevant publications.

\section{Positioning Indonesian Female Migrant Workers: An Indonesian Context \\ "Selamat Datang Pahlawan Devisa"} ("Welcome, Heroes of Foreign Exchange") was proclaimed by an enormous poster hung on the wall of the Arrivals area in Terminal 2 at Sukarno-Hatta Airport in Jakarta from the early 2000s until 2013. Many foreign passengers did not understand the meaning of "heroes" in that slogan (Chan, 2014). This text is no longer found at the Soekarno-Hatta Airport in Jakarta. However, to date, Indonesian migrant workers continue to be commonly labeled "heroes of foreign exchange".

For Indonesians, however, the identity of these "heroes of foreign exchange" has become common knowledge following a widespread government campaign to bestow the migrant workers with that title. The text at the airport is a sign of recognition and gratitude, honoring migrant workers. Every year, Indonesia receives trillions of rupiah in foreign exchange from the fruits of the labor of these migrant workers. These workers send their wages, for which they have worked so hard while overseas, to feed their families in their hometowns. In 2014, the head of the National Body for the Placement and Protection of Indonesian Migrant Workers (BNP2TKI Badan Nasional Penempatan dan Perlindungan Tenaga Kerja Indonesia), Nusron Wahid, stated that Indonesian migrant workers generated approximately billion dollars (approximately 100 trillion rupiahs) in foreign exchange annually (Wahyuni, 2013). The following table 1 shows the number of Indonesian migrant workers sent to other countries, such as to Saudi Arabia, Kuwait, Malaysia, Korea, and Japan, between 2011 and 2013. The table also shows the amount of foreign exchange they have generated for the economy. In comparison to the amount of foreign exchange generated by other sectors of the economy in 2013, we see that foreign workers are the second-largest generator of foreign exchange in Indonesia (at 
Table 1. Indonesian migrant workers and foreign exchange earnings

\begin{tabular}{cllll}
\hline Year & $\begin{array}{c}\text { Number of Migrant } \\
\text { Workers Sent Abroad }\end{array}$ & $\begin{array}{c}\text { Number of Female } \\
\text { Migrant Workers }\end{array}$ & $\begin{array}{c}\text { Number of Male } \\
\text { Migrant Workers }\end{array}$ & $\begin{array}{c}\text { Amount of Foreign } \\
\text { Exchange Generated }\end{array}$ \\
\hline 2011 & 586,802 & 376,686 & 210,116 & 67 trillion \\
2012 & 494,609 & 279,782 & 214,825 & 69.9 trillion \\
2013 & 512,168 & 276,998 & 235,170 & 88.6 trillion \\
\hline
\end{tabular}

Source: BNP2TKI, 2015 (Center for Research and Information Development, 2015)

88.6 trillion rupiahs), following closely behind the top sector, the oil and gas industry (which generated 110 trillion rupiahs during the same period).

According to historical records, Indonesian migrant workers were first sent abroad during the Dutch colonial period in 1890 (BNP2TKI, 2011). These people were employed in Suriname, on Dutch plantations, or in New Caledonia in 1896 (Subiyantoro, 2014). After Indonesia's independence in 1945, Indonesian migrant workers began to work in other countries such as Saudi Arabia and Malaysia. However, in these instances, workers went abroad at the invitation of family members or went on their own initiative. In 1970, Indonesian migrant workers were only sent abroad on a large scale and in an organized manner. The Department of Labor, Transmigration, and Cooperatives sent numerous workers through its Interregional Migrant Labor (AKAD) and International Migrant Labor (AKAN) programs, based on Government Law No. $4 / 1970$. Since then, the foreign placement of Indonesian migrant workers has involved the private sector (companies that use migrant labor or private parties which manage the placement of migrant laborers).

This generation of foreign exchange is given government recognition through expressions of gratitude such as the banner that hung in the airport arrivals terminal. However, it does not reflect the actual situation of Indonesian migrant workers who continue to face considerable risks to their well-beingparticularly the female migrant workers. The female migrant workers are often depicted in the media and in everyday discourses as people who are physically and psychologically oppressed. This is evident in many cases of violence, such as the cases of Siti Hajar, Nirmala Bonat, or Ceriyati (Antara News, 2007), or, in 2014, Erwiana Sulistyaningsih, who was tortured and burnt by her boss and subsequently left at the Hong Kong International Airport (Chan, 2014). However, when discussing the oppression and subjugation of the female migrant workers, it is not sufficient to focus only on the physical and psychological violence they face at the hands of their bosses abroad. Domestically, the female migrant workers are generally mistreated by their fellow Indonesians and often face discrimination from other Indonesians while living in their own country. Thus, this article focuses on the positioning of these female migrant workers in the Indonesian context.

The experience of female migrant workers is discussed dynamically in space and over time. There is a robust structure that continuously reproduces the discourse related to their life, and position including their stereotypes and marginalization in society. Such a social structure is encompassing both material and symbolic dimensions (Giddens, 1984). This social structure is the product of interaction, and as such, is an accustomed structure, enabling it to become solid and deeply rooted. The female migrant workers are positioned within a social structure which continuously undergoes a structuration process of being formed and positioned as objects. They are thus always formed and positioned similarly as objects.

For our purposes, positioning means the position of a person in a particular space and 
time, in the context of their social relationships with others (Giddens, 1984). These social positions are organized as a structure within which we can find domination, legitimization, and identity (Lamsal, 2015). Understanding such positioning is important, primarily because it is not only connected to broader social relations (such as class issues) but also gender issues. This positioning both exists and often occurs in the context of power relationships between them and other Indonesian people. Positioning as related to gender, in this case, is evidenced through the differential treatment of the male and female migrant workers.

This positioning involves the dynamics of space and time. In a spatial context, this positioning occurs in everyday life. They are often the objects of discussion because of the cases of violence they face in foreign lands. Indonesian informants who have commented on such cases show, on the one hand, a sense of empathy for the treatment of the female migrant workers, and on the other, a tendency to position them based on stereotypes. Such positioning is related to their social class, particularly their perceived attitude and the need to be "educated". In one interview with $\mathrm{SB}$, an ordinary woman from Central Java, on the 12 May 2014, the informant stated that the female migrant workers are ignorant of etiquette and as a consequence they are mistreated by their bosses. Meanwhile, another respondent, $\mathrm{P}$, an office worker in Central Java, on 17 May 2015, stated that they must be given a better moral education so that they do not become victims of violence, particularly sexual violence. Such perceived behavior of the female migrant workers shows class-related stereotypes and positioning; in the feudal period, the lower social classes were often identified as lacking in etiquette and displaying rude behavior.

By assimilating the above diverse perspectives, it is crucial to analyze the positioning of female migrant workers in a specific niche - a social setting, which is
Soekarno-Hatta International Airport as an ideal site for such a study because the positioning of different entities occurs in that space.

\section{Positioning, Social Class, and Power Relations}

Each social class is positioned differently. Historically, social classes, which were considered (or considered themselves) more important, such as the nobility and bourgeois, had more significant opportunities to position themselves in their relationships and interactions with other social classes. Capital is one aspect that explains a person's position of power in social relationships. If power is understood here as something spread throughout society, this concept negates the female migrant workers as they become increasingly subordinated. Power, according to Foucault, is not held by a person but instead exercised, and the legitimacy of power is established through normalization processes that are based on social constructs (Rossi, 2017). The inclusion and exclusion of persons considered "normal" and "abnormal" are realized through the use of power and knowledge by persons who follow their own rules (Foucault, 1980).

The indistinct subject of Foucault's concept of power becomes more distinct when power is understood as a field of force or competing discourse (Scott, 1988), as a struggle of positioning which includes socio-historical dynamics (Allen \& Goddard, 2014) and the subject's structure (habitus) and in which capital explains the existence of the subject. In his concept of habitus, Bourdieu argues that structures are the meeting between the social and individual. The individuals or the groups experience processes of both internalization (adapting outside input) and externalization (influencing structural dynamics by expressing the self) (Ningtyas, 2015). Habitus, thus, is a meeting between the social and internal, which explains the possible capital held by the subject. 
The greater the capital one holds the more significant the power one obtains, which has implications for one's position in the community. However, Bourdieu emphasizes that, by capital, he does not simply mean financial capital as found in the works of Karl Marx, but also other forms of capital: symbolic capital and cultural capital (Bourdieu, 1987). Symbolic capital is individual values that form a symbolic character considered beneficial to persons in their relationship with their community, including but not limited to social status, creativity, leadership, and bravery. Meanwhile, cultural capital is capital obtained by individuals after the individuals in question interact with the culture around them, thus giving them values that affect their social interactions (Al-Fayyadl, 2015). Cultural capital can include such things as education and language. The noble family, for instance, is generally positioned higher than other groups because they are thought to have greater symbolic and cultural capital. The are considered having social status, good language, and education even though they may not have financial capital or even any of the capitals mentioned above. Meanwhile, lower social classes are often marginalized because they are considered uneducated, non-compliant, and lacking in etiquette-this occurs even when, following Bourdieu's concept of capital, they actually have symbolic and cultural capital.

What is interesting when examining the situation of the female migrant workers is the question of why they continue to be positioned peripherally within the airport space even though they have various forms of social and economic capital? The issue here is that there is a historical construction that has continuously been reproduced over space and time to marginalize their position. When such practices continue to be reproduced, the migrant's capital will continue to be unimportant. However, this structure is not a permanent and immutable one; in specific spaces or times, there are dynamics that can change it, though it may take a relatively long period of time.

If Bourdieu sees positioning as a historical normalization structure, Giddens argues that it is an organized social system that can take the form of routine social practices which are maintained from period to period (Giddens, 1984). All subjects are positioned in space and time and also relationally within this social structure. Social positioning is done by reproducing social practices over time. This concept is similar to Bourdieu's concept of habitus above because there is a continuous reproductive process. People are unaware that something is constantly being reconstructed; it appears as natural or proper. For instance, over time, persons such as domestic workers have been normalized as being lower in standing than other elements of Indonesian society; as such, when they receive the differential or discriminative treatment, it is considered natural.

Numerous efforts have been made, particularly by Indonesian feminists, to change this naturalized positioning. One example targets a fundamental issue by changing the terminology used. The term " $b a b u$ " ("servant"), in common usage during the colonial period, has been dynamically transformed to "pembantu rumah tangga" ("domestic worker") and, later, "pramu wisma" ("housekeeper"). The term TKW, which is often considered pejorative, has since been replaced with the terms "buruh migran" ("migrant laborer") or "pekerja migran" ("migrant worker"). However, as the underlying mental schema (Fiske et al., 2011) and normalization process have remained the same in Indonesia and other countries where such workers are employed, this change in terminology is essentially meaningless.

Giddens centralizes this issue of positioning. He argues that social positioning is structurally organized where dominance and legitimacy meet (Giddens, 1984). Social 
positions, he writes, also involve particular identities within the framework of social relations, such as power relationships. This positioning is enduring and practiced through the process of identification by one group against another. Such identification is often made by connecting the legitimacy of power and normalization to one's social position.

When discussing the positioning of the female migrant workers within social relationships, there is a question of which social relationships should be explored. As explained by Bourdieu and Giddens, groups such as the female migrant workers are socially positioned as being of lower standing. However, Bourdieu and Giddens do not explicitly discuss the role of gender relations in the positioning process. Indeed, gender dimensions are evident in the positioning of the female migrant workers, who are distinguished in practice from the male migrant workers. As such, the structure is not only formed by the normalization process related to social class, but also related to gender (McGinn \& Oh, 2017). Although not all female migrant workers experience discriminatory positioning in their interactions with other passengers, their sense of being treated justly or unjustly is likewise related to the normalization process. If they consider the structure to be normal, they will not recognize any unjust treatment they receive.

Women experience marginalization, stereotypes, and exploitation in their life due to the masculine domination intensely practiced in society (Udasmoro \& Anwar, 2019). However, those discriminative practices are always connected to other social categories, such as social class, age, education, and ethnicities (Crenshaw, 2013). Crenshaw also argues that in intersectional power relationships, certain groups of women have more privilege than other groups. Intersectionality is defined as "an approach to research that focuses upon mutually constitutive forms of social oppression rather than on single axes of difference. Intersectionality is not only about multiple identities but is about relationality, social context, power relations, complexity, social justice and inequalities" (Hopkins, 2019 , p. 937). Women from the lower class social levels, for instance, can experience more exploitation than other groups with more financial capital (Wibowo et al., 2020). The discrimination is also experienced by young women because of their age (Sutopo \& Putri, 2019).

Mohanty also argues that in cosmopolitan countries, women are oppressed differently by the dominant power (Mohanty, 1988). She also argues that in cosmopolitan countries, there are always systems put in place by that dominant power in order to suppress the marginal groups for their own best interest. Women are not a singular entity. They have their history, geographic, and cultural background that makes them not equal, not only vis-à-vis men but also in their group (Hvenegard-Lassen et al., 2020). Certain groups of women might also be excluded because of their ethnicity or age (Apriliyanti, 2018). Women coming from lower social classes are sometimes excluded from many different opportunities (Grabe, 2020). They are, for instance, excluded from networking and groups. The subordination of women from the lower social classes happens in many different ways, in private and public spheres (Carey et al., 2018). In many cases also, women coming from lower social classes are considered as other (Hopkins, 2019). The female migrant workers in Indonesia are considered as other because they are placed lower compared to the higher class social women who usually dominate the usage of the airport.

Such positioning of the female migrant workers, who are considered inferior and uneducated-stereotypes always connected to their "provincial" ways and manners-has continued, and the positioning of different social classes also affects the power relationships between the non-migrant workers and the 
migrant workers. In this context, the exercise of power is often used to determine the identity of the "other", who is generally considered to be of lower standing (Collins, 1998). The exercise of power in this positioning is interesting to observe, particularly its occurrence in an international airport and its connections with gender relations and social class. Space is always positioned differently where the power is always exercised in many different ways (Udasmoro \& Anwar, 2019).

Symbolically, the term TKW use to mention female migrant workers in Indonesian context is a pejorative or value-laden acronym. Materially and practically, the female migrant workers are also treated less justly than male migrant workers. The view that they are more easily dominated means that airport officials (predominantly men) attempt to use particular spaces to exercise their power. However, female migrant workers are not passive subjects; they respond to the negative treatment they face by attempting to better position themselves or respond to others' positioning using their available strategies (Eleanor et al., 2018). The fact that they too have capital, be it financial, cultural, or symbolic, gives them greater confidence in responding to the situations they face.

\section{Female Migrant Workers and Gender Discourse}

The lower positioning of the female migrant workers in Sukarno-Hatta International Airport has had consequences that can be seen in the daily practices. Many females who are not migrant workers attempt to position themselves as being unlike the female migrant workers. They do so by, for instance, wearing clothes that differ from those worn by the female migrant workers, such as a vest. This clothing item typically worn by public officials and professionals is rarely worn by female migrant workers (Abror, 2020; Kurniawan et al., 2019). It is thus adopted by passengers who do not want to be considered migrant workers. One lecturer at a prestigious tertiary education institute in Yogyakarta, FT, said:

"Gosh, it is better to buy a vest. I do not mind if it is a bit pricey, rather than have people think I am a TKI (migrant worker)"

(A lecturer from a public university in Yogyakarta, data taken on 15 November 2016)

The above discourse shows incidences of class positioning occurring. Vests, as symbols of a higher social class, are used as tools to position oneself and to differentiate the self from the other. Vests are often used to increase the wearer's bargaining power in social interactions. As such, having an "upper-class" identity is often accomplished by purchasing and using certain symbols (vests, in this case). The fact that the above respondent purchased a vest simply to avoid being mistaken for a female migrant worker begs the question of how low the migrant workers are positioned, to the point that it is considered acceptable to spend a significant sum of money to avoid looking like them. This practice of positioning is omnipresent in daily discussions, and it is perceived as normal when presented in speech (Udasmoro, 2017). There is an enduring normalization process that occurs because the community is conditioned to believe that it is proper for the female migrant workers to be positioned as lower class. It is also considered proper to respond by purchasing a vest to avoid being mistaken for a migrant worker.

Another statement, paradoxically from a women's rights activist, positions the female migrant workers as a group to be avoided:

"I have never taken an airplane that transits in Abu Dhabi or Kuwait." "Why?"

"I do not want to be in one group with them because people will think I am a TKW (female migrant worker)" 
(A conversation with, $\mathrm{R}$, a female lecturer on 20 February 2015)

In the above response, the statement shows a common occurrence, that when Indonesians travel abroad, particularly on aircraft carrying female migrant workers, they attempt to avoid waiting in the same queues as migrants for airline ticketing services. Many people likewise feel uncomfortable sitting near them. Some give reasons such as "they are noisy", while others say "they embarrass us with their provincial ways". Other passengers will say, "they are always making a ruckus and cannot queue". Such comments are made everyday, and are stated explicitly by other Indonesian passengers. The female migrant workers are positioned as "others" in terms of their actions, and thus passengers consider it proper and natural to exclude them from social relations at the airport. There is an issue of the normalization process where people tend to see other people and believe that they must all be like one's self. Everyone who is the "same" is considered "normal" whereas those who are "different" are considered "abnormal". Those who are considered "abnormal" are then excluded, often to the point that other passengers feel disturbed if the female migrant workers greet or otherwise speak to them. The non-migrant workers' group are unable to accept this "difference".

One important thing to note in discussing the passengers' aversion to being considered the same as a female migrant worker is its effect on their position. Symbolically, they do not want to be considered as migrant workers, whom they consider to have a lower position in Indonesian society. In practice, the fact that the female migrant workers are often segregated at the airports also makes other passengers avoid being mistaken as migrant workers.

Several migrant workers have stated that they have experienced differential treatment at airports in Indonesia. They face various kinds of mistreatment, both institutional and individual, particularly in regards to their finances. Since 1999, female migrant workers have been allocated to a particular terminal. Initially, it was Terminal 3 (Silvey, 2006); however, because the name "Terminal 3" was appropriated for a new terminal used by certain public airlines, their terminal has been designated Terminal 4 . This shift to Terminal 4 signified a shift in their position, placing female migrant workers at the bottom. Even when they landed at another international terminal, such as Terminal 2, they always had to be taken to Terminal 4. Later, migrant workers began landing exclusively at Terminal 2D, which has the same function as Terminal 4. From there, they are taken by a designated bus to their points of origin; the cost for this trip is four to five times as much as they would pay if they took public transportation on their own. The Ministry of Immigration and Labor has argued that these designated buses are meant to protect them (Kompas, 2009).

The experiences of several workers indicate that, although the terminal and designation may be new, it is still used to pressure and extort money from migrant workers. The following statement was made in a national newspaper by a migrant worker who shared her experiences in the "terminal for migrant workers":

I thought that Soekarno-Hatta Airport had changed and become more professional in its service compared to twelve years ago. Gosh... it turned out that I was wrong after hearing the stories of my fellow migrant workers and reading articles such as this. Some officials would throw down the cell phones (of migrant workers) if they refuse to pay a fine for bringing home more than two cell phones.

Did the government not prepare a particular terminal for Indonesian migrant workers to ease our return to our points of origin? But these facilities, they just make things difficult for migrant workers? Hello... hello, administrators of Soekarno-Hatta/ 
BNP2TKI/Representatives, are you deaf or blind to the shrieking of us migrant workers, whom you mistreat in our own country? Stop calling us the Heroes of Foreign Exchange!! (Ma, 2012)

Nevertheless, the use of different waiting rooms for migrant workers and non-migrant workers is not only for the workers' protection. In an Indonesian context, cognitive borders are created between such women as lowerclass individuals (i.e. migrant workers) who transgress a norm in sharing the same space as upper-class individuals (i.e., women traveling for other purposes). This tendency is deeply historical, with similar class positioning being present in the household context through the use of such terms as wong mburi (people out the back) to refer to domestic helpers. These cognitive borders are created within airports, not only in the separation of terminals but also in the separation of waiting rooms.

The inequitable positioning of the female migrant workers has caused them to respond with various strategies, using the symbolic capital of agency in the form of courage and self-confidence. They understand that one's fashion sense has a specific meaning and thus understand that its symbolism, as it relates to their choice of clothing, is important. Many female migrant workers thus wear clothing that they consider capable of helping them leave the exclusive (to them) space of the airport. They wear vests in an attempt to avoid being negatively positioned, for instance. The financial capital, that they earn while abroad, allows them to use such a strategy to oppose this positioning as being lower class and the ruling class's legitimization of vests as only belonging to the non-migrant group. Here, the marginalization process is practiced due to the feudalistic view from the high-class people towards the female migrant workers. Women sometimes are treated unequally not only because of their gender but also because of their social class (Mohanty, 1988).
Another strategy is using a particular airline in the hopes that airport officials will not expect there to be migrant workers on board; several airlines, particularly the more expensive ones, are often considered to be used exclusively by upper-class passengers. On returning from a job in Singapore, one female migrant worker attempted to avoid the BNP2TKI official who would have taken her from Terminal 2 to Terminal 4 . She stated that she had deliberately selected Singapore Airlines, known for its high prices, on the assumption that the airport officials would not be interested in passengers from this airline, because most of them were upper-class passengers capable of paying the more expensive ticket prices. The worker in question said that she had hoped nobody would notice her, and thus she would not be taken to Terminal 4. In Terminal 4 she knew that she would face discriminative acts, more expensive fees, and longer waiting times (as she would have to wait for other female migrant worker heading to the same destination). The discrimination process always intersects between gender and other social categories in many different aspects (Rice et al., 2019), like in the above case.

In the following example, this migrant's clothing choice was not one stereotypically associated with the female migrant workers, such as a headscarf. She wore high heeled boots and a tight shirt and carried a brandname knapsack. However, the airport official still told her to go to Terminal 4 to be taken to her hometown. This migrant worker had asked another woman, who was not a migrant worker, to help her negotiate with the official so that she could leave through Terminal 2. There followed a discussion between the three of them: the BNP2TKI official, the migrant worker, and the Singapore Airlines passenger.

Woman : What is this Mas?

Official : Bu, she has to go in the car meant especially for TKW (migrant workers). 
Worker :Mas, my family is waiting outside. They have come all the way from Purwokerto.... My whole family, Mas ... my father and my mother and my siblings... in two cars ....

Official : You cannot, Mbak. You know the rules, don't you?

Worker : Yes, Mas, but...

Official : You can't Mbak, you just can't. We're just doing our jobs here. Woman : Come on now, Mas. Just let her go home with her family. They are waiting outside.

Official : We can't, Bu, sorry. The TKW (migrant worker), according to the rules, must use the allocated transportation.

Woman : Eh, by the way, Mas. How can you know that she's a TKW? I came from the same airplane, but you're not telling me to take the bus. She doesn't have any signs on her. Official : Yeah, of course I know Bu...

Woman : How can you tell that?

Official :Her [body] appearance is different, for one...

(Conversation taken on the 2 February 2013)

The above discussion shows a female migrant worker being identified, differentiated from a non-migrant worker, and positioned through her gestures and body, including her body form and language. The positioning of body language has also undergone a lengthy normalization process in Indonesia, especially in class issues. There is lengthy historical background regarding how actions and body language differentiate the upper and middle class, mainly - for women - in terms of gender (Crenshaw, 2013). In Javanese culture, for instance, the manner in which a woman sits or stands is determined by cultural rules regarding gestures and body language.

The positioning towards female migrant workers is further done by the airport officials through a system of double discrimination. First, as in this case, the airport official labels the female migrant worker with identification based on her gestures and body language. The second form of discrimination is the system that places them in Terminal 4 , a system enforced by airport officials. The above sentence "We can't, Bu, sorry. The TKW, according to the rules, must use the allocated transportation," shows differential treatment of them owing to their "differentness". As such, the positioning of the female migrant worker involves the enforcement of a system. Airport officials follow this system every day while carrying out their duties, to the point that it becomes a compulsory routine; if the system is not enforced, airport officials feel as though they have not done their duties well. The system created and enforced here shows that the positioning of the migrant worker is not spontaneous but rather planned.

The female migrant worker also recognizes this double discrimination and seeks out alternatives to avoid the issue. The way she dressed, chose her flight, and chose a friend as she was leaving the aircraft shows that she took steps to leave the system which differentiates her from other people. First, she attempted to avoid being differentiated from other passengers by "becoming" like the other passengers. Second, she saw no need to differentiate herself in her interactions with others, thus positioning herself the same as all other passengers. The airport official, however, did not see it that way and used his legitimized authority to position her, including to dictate what she had to do. In this power relationship, the female worker had strategies and capital that were used to leave Terminal 2 without the airport officials knowing that she was a female migrant worker. However, because of the positioning structure, people with certain gestures, bodies, and body language are normalized as being from the lower-class, her efforts failed. 
"I have already come home to Indonesia several times. I do not need anyone to take me home. I know the way home," said the female migrant worker. The official did not heed her.

(Conversation with the migrant worker on 2 February 2013)

The airport official in the above example completed his duties because he was enforcing existing rules, but he also personally positioned the migrant worker. The legitimacy of this system is positioned even more clearly when she has no basis for refusing to be taken to Terminal 4. The airport officials' dominance over the female migrant worker, using the legitimacy of bureaucratic power, puts them in a position of strength and thus makes it impossible for the female migrant worker to be in control of the situation. However, efforts by the migrant worker do not always fail. Many of them can successfully navigate through this situation. One female worker stated that she preferred to go through the airports in Yogyakarta or Surakarta, which she considered friendlier. "It is better to go through Yogya. The officials are nice and we do not have to go to another terminal." Choosing to land at an international airport outside Jakarta, such as in Yogyakarta or Solo, is becoming a strategy for the female migrant workers who want to avoid being positioned (be it systematically or personally) by airport officials.

\section{Conclusion}

Soekarno-Hatta International Airport is a force field used by certain people to exercise power or to resist against the use of power. This airport is used by the non-migrant workers, by passengers or airport officials, to exercise power, discipline, or dominance over the female migrant workers for their own goals and motivations. Meanwhile, the female migrant workers show resistance and respond to attempt to escape this power.
The first motivation is more individual and related to the long-standing normalization process in which the female migrant workers and their profession are positioned as inferior in an Indonesian context. In this individual positioning, the non migrant workers, through their frequent positioning of the female migrant workers as inferior, subordinate them. They practice symbolic subordination by using items that are not usually used by the female migrant workers, such as clothing, tools, transportation equipment, and the like. Second, there is a system used in the airport space to position the female migrant workers. Discourse is presented through this positioning, such as symbols used, the distance maintained, and differentiation of them.

In various cases, marginalization and stereotypes are practiced in many different ways. Female migrant workers haveexperienced discrimination and stereotypes exercised by the Indonesians due to their gender and social class. The forms of discrimination varied from the material to the symbolic aspects of discrimination. Materially, female migrant workers become victims of the airport workers who benefit from their economic capital. This is quite different than with male migrant workers because airport workers usually position women as targets and victims because they are considered weak. They also victims of symbolic discrimination and stereotypes when they are positioned as inferior than other passengers. They are considered lower because they are viewed as coming from lower-class families. The fact that they can contribute income to the country is not considered because of their physical appearances. Physical appearance is one of the signifiers in discriminating against Indonesian female migrant workers. The fashion system, for instance, is considered a necessary practice for women but not for men. Men are not really affected by the fashion.

However, the female migrant workers have responded to this positioning with their 
strategies. If the non-female migrant workers distance themselves from the female migrant workers by using symbols that they think the workers will not use, the female migrant workers do the opposite. They use the same symbols as the non-female migrant workers as an alternative strategy to facing double discrimination at the airport. These symbols, such as the fashion system or choice of the airline that are considered representative of the upper class, are used to avoid the effects of positioning (such as discrimination, extortion, and rules which differentiate them from other passengers).

The above situation shows that the discourse of discrimination, as related to gender and social class, is constantly present in space and time. This discourse is present in all spaces, no matter how small, especially in public spaces. Those who consider themselves as having higher social positions attempt to maintain their status by positioning those considered to originate from a lower social class as inferior to themselves. The positioning of "we" and "us" is an attempt to preserve the class structure that has been normalized throughout history. Such acts are continually practiced, but from time to time, there are changes in the dynamics. For example, it is important to keep in mind that the people positioned as lower-class people are not passive agents. In many different ways people continue to try to take control of their lives. The problem is that, when structures considered longstanding are practiced by those in higher social positions, then those structures will endure.

\section{References}

Abror, M. (2020). Wacana TKI dalam Novel Jatisaba Karya Ramayda Akmal. Poetika, 8(1), 64-78. https://doi.org/10.22146/ poetika.v8i1.56541

Al-Fayyadl, M. (2015). Kritik Sastra Prancis. Poetika, 3(2), 143-153. https://doi. org/10.22146/poetika.v3i2.10439
Allen, A., \& Goddard, R. (2014). The domestication of Foucault: Government, Critique, War. History of the Human Sciences, 27(5), 26-63. https://doi. org/10.1177/0952695114538990

Amr. (2016). Jumlah TKI Asal Jateng Capai 9633 Orang [Mass Media]. Okezone. https://news.okezone.com/ $\mathrm{read} / 2016 / 07 / 25 / 512 / 1446107 / j u m l a h-t k i-$ asal-jateng-capai-9-366-orang

Anggaunitairanantika, A., \& Hamidi, M. (2020). Emotional Entanglement and Community Empowerment of Transnational Migrants' Families: A Cross-Sectional Study in Malaysia and Indonesia. Global Social Welfare, 7(4), 1-10. https://doi.org/10.1007/ s40609-020-00191-3

Antara News. (2007). "Kasus Ceriyati Buktikan Indonesia Gagal Lindungi TKI" [Mass Media]. Antara News. https://www. antaranews.com/berita/66920/kasusceriyati-buktikan-indonesia-gagal

Apriliyanti, I. T. (2018). Aging Labor and Japanese Industry Performance: Lessons for Indonesia Policies. Jurnal Ilmu Sosial Dan Ilmu Politik, 22(1), 34-48.

BNP2TKI. (2011). "Sejarah Penempatan TKI Hingga BNP2TKI" [Government]. BNP2TKI. http://www.bnp2tki.go.id/ frame/9003/Sejarah-Penempatan-TKIHingga-BNP2TKI

Bourdieu, P. (1987). The Logic of Practice. Gallimard.

Butler, J. (1988). Performative Acts and Gender Constitution: An Essay in Phenomenology and FeministTheory. Theatre Journal, 40(4), 519-531.

Carey, G., Dickinson, H., \& Cox, E. M. (2018). Feminism, Gender, and Power Relations in Policy - Starting a New Conversation. Australian Journal of Public Administration, 77(4), 519-524. https://doi. org/10.1111/1467-8500.12324

Chan, C. (2014). Gendered Morality and Development Narratives: The Case of 
Female Labor Migration from Indonesia. Sustainability, 6, 6949-6972.

Collins, P. H. (1998). It's All in the Family: Intersections of Gender, Race and Nation. Hypatia, 3(3), 62-82.

Crenshaw, K. W. (2013). From Private Violence to Mass Incarceration: Thinking Intersectionally About Women, Race, and Social Control. Journal of Scholarly Perspective, 9(1), 21-50.

Eleanor, M., Carson, L., \& Yates, S. (2018). What can policymakers learn from feminist strategies to combine contextualised evidence with advocacy? Humanities and Social Sciences Communication, 4(104), 1-9. https://doi.org/10.1057/s41599-018-0160-2

Elias, J. (2013). Foreign Policy and the Domestic Worker: The Malaysia-Indonesia Domestic Worker Dispute. International Feminist Journal of Politics, 15(3), 391-410. https://doi.org/10.1080/14616742.2012.7 55835

Fiske, S. T., Cuddy, A., J. C., \& Glick, P. (2011). Universal Dimensions of Social Cognition: Warmth and Competence. Trends in Cognitive Sciences, 11(2), 77-83.

Ford, M. (2006). Migrant Worker Organizing in Indonesia. Asia and Pacific Migration Journal, 15(3), 313-334. https://doi. org/10.1177/011719680601500302

Foucault, M. (1980). Power/Knowledge: Selected interviews and other writings 1972-1977 (C. Gordon, Ed.). Harvester Press.

Giddens, A. (1984). The Constitution of Society: Outline of the Theory of Structuration. University of California Press.

Grabe, S. (2020). Research Methods in the Study of Intersectionality in Psychology: Examples Informed by a Decade of Collaborative Work With Majority World Women's Grassroots Activism. Psychology. https://doi.org/doi.org/10.3389/ fpsyg.2020.494309

Hopkins, P. (2019). Social geography I: Intersectionality. Progress in Human
Geography, 43(5), 937-947. https://doi. org/10.1177/0309132517743677

Hvenegard-Lassen, K., Staunaes, D., \& Lund, R. (2020). Intersectionality, Yes, but How? Approaches and Conceptualizations in Nordic Feminist Research and Activism. NORA - Nordic Journal of Feminist and Gender Research, 28(3), 173-182.

Keban, Y. (2000). International Migration, the Strategy for National Development and Globalisation in Sukamdi. In A. Haris \& P. Brownlee (Eds.), Labour Migration in Indonesia: Policies and Politics. Population Study Center, Universitas Gadjah Mada. Killias, O. (2010). 'Illegal' Migration as Resistance: Legality, Morality and Coercion in Indonesian Domestic Worker Migration to Malaysia. Asian Journal of Social Science, 38, 897-914. https://doi. org/10.1163/156853110X530796

Kompas. (2009, June 13). “TKW Ditahan Petugas, Kepala BNP2TKI Jumhur Hidayat: Itu Demi Melindungi Mereka". Kompas.

Kristina, A. (2020). Key Policy Challanges: Social Security for Migrant Workers. International of Religious and Cultural Studies, 2(1), 7-19. https://doi.org/10.34199/ijeacs.2020.04.02

Kurniawan, M. L. D., Prasetyo, H., Wicaksono, A., \& Akmal, U. F. (2019). Degradasi Puitika dalam Kontestasi Literasi Cerita KKN di Desa Penari. Poetika, 7(2), 216231. https://doi.org/10.22146/poetika. v7i2.51571

Kusuma, A. J., York, M. R., \& Wibowo, R. H. (2015). Violence Againts Indonesian Migrant Workers-A Causal Analysis. Jurnal Hubungan Internasional, 4(1), 47-57. Lamsal, M. (2015). The Structuration Approach of Anthony Giddens. Himalayan Journal of Sociology and Anthropology, V, 111-122.

Liao, T. F., \& Gan, R. Y. (2020). Filipino and Indonesian Migrant Domestic Workers in Hongkong: Their Life Courses in Migration. American Behavioral 
Scientist, 64(6), 740-764. https://doi. org/10.1177/00002764220910229

Loveband, A. (2007). Positioning the Product: Indonesian Migrant Workers in Taiwan. Journal of Contemporary Asia, 34(3), 336348.

Ma, L. (2012). “Soekarno-Hatta Seperti Ibu Tiri bagi TKI" [Mass Media]. Kompasiana. http://birokrasi.kompasiana.com

Mafruhah, I., Istiqomah, N., Mulyani, N. S., \& Rahardjo, M. (2016). The Placement Model for Indonesian Migrant Workers to Improve their Economic Welfare. Journal of Business and Economic Review, $1(1), 42-50$.

McGinn, K., \& Oh, E. (2017). Gender, Social Class, and Women's Employment. Current Option in Psychology, 18, 84-88. https://doi. org/10.1016/j.copsyc.2017.07.012

Mohanty, C. T. (1988). Under Western Eyes: Feminist Scholarship and Colonial Discourses. Feminist Review, 30, 61-88. https://doi.org/10.2307/1395054

Ningtyas, E. (2015). Pierre Bourdieu, Language and Symbolic Power. Poetika, 3(2), 154155. https://doi.org/10.22146/poetika. v3i2.10437

Platt, M. (2018). Migration, Moralities and Moratoriums: Female Labour Migrants and the Tensions of Protectionism in Indonesia. Asian Studies Review, 42(1), 89-106. https://doi.org/10.1080/10357823 .2017.1408571

Pratikno, R., Yazid, S., \& Dewi, E. (2020). Enhancing the Role of Remittances through Social Capital: Evidence from Indonesian Household Data. Asian and Pacific Migration Journal, 29(1), 30-54. https://doi.org/10.1177/0117196820920401

Radar Lombok. (2016). Kasus Kekerasan Terhadap TKI Masih Tinggi. Radar Lombok. http://www.radarlombok.co.id/ kasus-kekerasan-terhadap-tki-masihtinggi.html
Rice, C., Harrison, E., \& Friedman, M. (2019). Doing Justice to Intersectionality in Research. Cultural Studies <--> Critical Methodologies, 19(6), 409-420. https://doi. org/doi.org/10.1177/1532708619829779

Rossi, A. (2017). Foucault, Critique, Subjectivity. Journal of Cultural Research, 21(4), 337-350. https://doi.org/10.1080/14797585.2017.1 370486

Scott, J. W. (1988). Deconstructing EqualityVersus-Difference: Or, the Uses of Poststructuralist Theory for Feminism. Geopolitics Journal, 14(1), 33-51.

Setiadi. (2001). Masalah Reintegrasi Sosial dan Ekonomi Migran Kembali. Populasi, 12(1), 21-35.

Silvey, R. (2006). Consuming the Transnational Family: Indonesian Migrant Domestic Workers to Saudi Arabia. Global Network A Journal of Transnational Affairs, 6(1, January), 23-40.

Solidaritas Perempuan. (2014). Situasi Kekerasan dan Pelanggaran Hak Buruh Migran Perempuan dan keluarganya di Negara ASEAN. Solidaritas Perempuan.

Subiyantoro. (2014). Survival Strategies of the Javanese Language in New Caledonia. Humaniora, 26(1), 43-55.

Sururama, R., \& Nanuru, T. (2019). The Role of the Ambon City's Population and Civil Registration Office in Controlling Incoming Migration. Jurnal Ilmu Sosial Dan Ilmu Politik, 23(2), 163-177. https:// doi.org/10.22146/jsp.41525

Sutopo, O. R., \& Putri, R. D. (2019). Mobilitas, Negosiasi dan Transisi Perempuan Muda di Jawa Tengah. Jurnal Studi Pemuda, 8(1), 1-14. https://doi.org/10.22146/ studipemudaugm.45962

Udasmoro, W. (2017). The Language Construction of Muslims in French Contemporary Discourses. Indonesian Journal of Islam and Muslim Societies, 7(1), 77-99. https://doi.org/10.18326/ ijims.7il.77.99 
Udasmoro, W., \& Anwar, S. (2019). Contesting the Social Spaces: Gender Relations of Literary Communities in Yogyakarta and Surakarta. Indonesian Journal of Geography, 51(3), 346-356.

Wahyuni, N. D. (2013). “4 Juta TKI Sumbang Devisa Rp. 100 Triliun ke Negara" [Mass Media]. Liputan 6. www.liputan6.com/ bisnis/read/756717/4-juta-tki-sumbangdevisa-rp-100-triliun-ke-negara.

Wibowo, O. T., Udasmoro, W., \& Noviani, R. (2020). Understanding New Consumption Sites of Internet Cafe in Yogyakarta, Indonesia. Jurnal Ilmu Sosial Dan Ilmu Politik, 23(3), 237-249. 